\title{
PREVALENCE OF SEROLOGICAL MARKERS FOR CELIAC DISEASE (IgA AND IgG CLASS ANTIGLIADIN ANTIBODIES AND IgA CLASS ANTIENDOMYSIUM ANTIBODIES) IN PATIENTS WITH AUTOIMMUNE RHEUMATOLOGIC DISEASES IN BELO HORIZONTE, MG, BRAZIL
}

\author{
Victor de Barros KOEHNE ${ }^{1}$, Magda BAHIA ${ }^{2}$, Cristina Costa Duarte LANNA ${ }^{3}$, \\ Maria Raquel da Costa PINTO $^{3}$, Eduardo Alves BAMBIRRA ${ }^{4}$ and Aloísio Sales da CUNHA ${ }^{1}$
}

\begin{abstract}
Context - Patients with autoimmune rheumatologic conditions and celiac disease tend to have a variety of autoantibodies, many of which have no clear pathogenic role. The literature contains frequent reports of celiac disease being more prevalent in patients with rheumatologic diseases, although this remains controversial. Objectives - To investigate the prevalence of positive serum tests for celiac disease, particularly IgA and IgG antigliadin (AGA) antibodies and IgA antiendomysium antibodies (EmA) in patients with autoimmune rheumatologic diseases. A second aim was to correlate positive serum tests with prednisone and immunosuppressant medication. Methods - A total of 190 adults and pediatric patients with a variety of autoimmune rheumatologic diseases (systemic lupus erythematosus, rheumatoid arthritis, juvenile rheumatoid arthritis and spondyloarthrophathies) were evaluated and tested for IgA and IgG antigliadin-antibodies and IgA antiendomysium antibodies. Patients with positive serum tests underwent endoscopic duodenal biopsies for pathology studies. Results - There were four positive sera (2.1\%) for AGA IgA, all of which tested negative for AGA IgG and EmA. Three sera (1.6\%) tested positive for AGA IgG; all were negative for AGA IgA and EmA. The EmA test at a 1:2.5 serum dilution tested positive in 94 patients (49.5\%); at a 1:5 serum dilution it was positive in 41 patients (21.6\%). Eleven subjects tested positive for EmA at 1:40 dilution; and all of these tested negative for IgA tissue antitransglutaminase (tTG) antibodies. Nine of the 11 EmA-positive patients and all 7 patients with positive antigliadin antibodies tests underwent duodenal endoscopic biopsies, and no significant changes were demonstrated in their duodenal mucosa. A positive EmA was associated with elevated optical density AGA IgA readings; however, there was no relationship between positive EmA and AGA IgG optical density readings. Prednisone and immunosuppressant use were unrelated to AGA IgA optical density readings or AGA IgG readings. These drugs were associated with fewer positive EmA tests. Conclusions - Positive AGAA, AGAG or EmA results are probably nonspecific for the presence of celiac disease among autoimmune rheumatologic disease patients. The intake of prednisone and immunosuprressant drugs seems to reduce the prevalence of $\operatorname{IgA} \mathrm{EmA}$, but it does not interfere with antigliadin antibodies tests.Further studies are required to estimate more accurately the prevalence of this disease in rheumatologic patients.
\end{abstract}

HEADINGS - Celiac disease. Rheumatic diseases. Sorologic tests.

\section{INTRODUCTION}

Celiac disease $(\mathrm{CD})$ is a condition of sensitivity to gluten (a mixture of proteins in wheat, rye and barley) causing an immunologically based enteropathy in genetically predisposed subjects. This disease manifests both cellular and humoral immunity responses; humoral antibodies are used in diagnosis and follow-up ${ }^{(17,26,50,51)}$.

CD may also be associated with other inherited diseases involving autoimmunity mechanisms, such as type I diabetes mellitus, Down's syndrome and thyroid conditions, especially Basedow-Graves' disease and Hashimoto's thyroiditis ${ }^{(18,26,27,50,53,56)}$. An association

Study undertaken at the Medical School of the Federal University of Minas Gerais, Belo Horizonte, MG, Brazil.

Departments of ${ }^{1}$ Internal Medicine; ${ }^{2}$ Pediatrics; ${ }^{3}$ Orthopedics; ${ }^{4}$ Pathology and Legal Medicine.

Correspondence: Dr. Victor de Barros Koehne - Rua Muzambinho, 104/701 - 30310-280 - Belo Horizonte, MG, Brasil. E-mail: vbkoehne@terra.com.br 
between $\mathrm{CD}$ and autoimmune rheumatologic diseases has been posited by various authors, but this possibility remains controversial, since these reports are usually based on descriptive case reports ${ }^{(19,22,26,40,41)}$.

Although previously considered rare, $\mathrm{CD}$ is being diagnosed with increasing frequency worldwide; prevalence rates are $0.33 \%$ to $1.5 \%$ in Europe $^{(6,49)}$ and $0.7 \%$ to $1.3 \%$ in the United States $(8,48,50)$.

Studies in various regions of Brazil have pointed to prevalence rates ranging from $1 / 273$ to $1 / 1000$, depending on the study population ${ }^{(13,37,42,46)}$.

The growing number of diagnosed CD cases is due not only to an increased recognition of atypical forms, but also to more readily available serological and endoscopic diagnostic methods at present. In Brazil, however, laboratory techniques for serological tests are generally not standardized; their accuracy thus remains low for screening purposes when selecting patients for intestinal biopsies ${ }^{(1,26)}$.

The purpose of this study was to help improve the assessment of serum tests for $\mathrm{CD}$, especially antigliadin and antiendomysium antibodies, in adult and pediatric patients with autoimmune rheumatologic diseases.

\section{METHODS}

A clinical cross-sectional study of 190 adult and pediatric patients was carried out in the Rheumatology Outpatient Unit of the Clinical Hospital (Hospital das Clínicas), Federal University of Minas Gerais, in Belo Horizonte, MG, Brazil, from November 2005 to February 2008. Individuals with a confirmed diagnosis of systemic lupus erythematous (SLE), rheumatoid arthritis (RA), juvenile rheumatoid arthritis (JRA) and spondyloarthropathies were included in this study.

Participants signed a free informed consent form. The Research Ethics Committee of the Federal University of Minas Gerais approved this study.

Each participant answered a questionnaire; blood was taken for laboratory tests when the patients were scheduled for hematologic tests to control their rheumatologic condition.

Laboratory analysis comprised the ELISA immunoenzyme assay testing for IgA and IgG antigliadin antibodies (AGAA, AGAG) as described in a modified Volta et al. ${ }^{(54)}$ method $^{(1)}$. The cutoff point for AGAA test positivity was an optic density of 0.041 and over; the corresponding cutoff point for AGAG test positivity was $0.140^{(1)}$.

Antiendomysium antibodies were tested using the indirect immunofluorescence technique as described by one of the modified Chorzelski et al. ${ }^{(4)}$ methods..$^{(1)}$. Sera were tested at a 1:2.5 dilution; sera that showed positive fluorescence at 250x magnification were diluted to $1: 5$ and $1: 40$, and the test was repeated. EmA-positive patients were those with sera that fluoresced in an endomysial "honeycomb" pattern at a 1:40 dilution ${ }^{(1)}$.

IgA (tTG) tissue antitransglutaminase antibodies were tested in EmA-positive sera at 1:40 using the INOVA QUANTA Lite h-tTG IgA kit (INOVA Diagnostics Inc, San Diego, California, USA).
Nephelometry (IMMAGE Immunochemistry Systems IGA, Beckman Coulter Inc, Fullerton, California, USA) was used for dosing IgA class serum immunoglobulins in patients that were AGGA and EmA-negative and AGAG-positive ${ }^{(32)}$. IgA reference values for adults were 82 to $453 \mathrm{mg} / \mathrm{dL}$.

EmA-positive patients (1:40 dilution) and AGAA or AGAG-positive patients underwent upper digestive endoscopy with duodenal biopsies, examined by an expert pathologist. At least six mucosal fragments were taken from the second portion of the duodenum below the papilla using a common $6 \mathrm{~mm}$ biopsy forceps (Fujinon); a Fujinon EG 200FP gastroscope was used for examination. Histological criteria for systematic sample analysis were those of the North American Gastroenterology Association ${ }^{(50)}$ which match the Marsh criteria ${ }^{(35)}$.

Files of AGAA, AGAG or EmA-positive patients were studied in search of data on anemia; patients were inquired directly as to the presence of chronic diarrhea to find clinical symptoms suggesting the presence of $\mathrm{CD}$. Correlations were sought among positive serum tests and the use of prednisone and immunosuppressant drugs.

The Kruskal-Wallis test was applied for statistical comparisons among more than two groups. The Mann-Whitney test was applied for comparisons between two groups. The chi-square and Fisher's exact test were applied to compare qualitative variables. Spearman's correlation coefficient (rho) was applied to assess the intensity of relations (rho $\leq 0.3$ : weak correlation; $0.3<$ rho $\leq 0.6$ : moderate correlation; $0.6<$ rho $<0.8$ : moderate to strong correlation; rho $\geq 0.8$ : very strong correlation). The chi-square test was applied to investigate associations among categorical variables. The significance level for all statistical tests was $5 \%$.

\section{RESULTS}

There were 190 patients, 141 of which $(74.2 \%)$ were female and $49(25.8 \%)$ were male. The mean age was 38.8 years; the standard deviation was 17.7 years, the median age was 39.5 years, the maximum age was 76 years and the minimum age was 2 years. Among these patients $69(36.3 \%)$ had SLE, 48 $(25.3 \%)$ had RA, $32(16.8 \%)$ had JRA, and 41 (21.6\%) had spondyloarthropathies.

Patients were allocated to four groups:

group $1-$ SLE patients $\mathrm{n}=69(36.3 \%)$;

group $2-$ RA patients $\mathrm{n}=48(25.3 \%)$;

group 3 - JRA patients $n=32(16.8 \%)$;

group 4 - spondyloarthropathy patients $n=41(21.6 \%)$

Specific diagnoses were as follows: ankylosing spondilitis (27 cases), Reiter's reactive arthritis (1 case), psoriatic arthritis (6 cases), Crohn's disease enteropathy (1 case), and undifferentiated spondyloarthropathies (6 cases).

There were statistically significant differences in age among the four groups; JRA usually affects younger subjects before age 16 years, which is a necessary criterion for this diagnosis. There was also a statistically significant gender difference among the four groups, as males predominated only in the spondyloarthropathy group. 


\section{IgA and IgG antigliadin antibodies}

There were no statistically significant differences among groups in relation to AGAA and AGAG (Table 1).

Four patients tested AGAA-positive: the serum optic density was 0.042 in an RA patient, 0.051 in a JRA patient, 0.076 in an SLE patient, and 0.102 in another RA patient. All were AGAG and EmA-negative, and did not present diarrhea or anemia.

Three patients tested AGAG-positive: the serum optic density was 0.148 in an RA patient, 0.163 in an SLE patient, and 0.197 in a patient with Crohn's disease associated spondyloarthropathy. Serum IgA levels in these adults patients were $177 \mathrm{mg} / \mathrm{dL}, 510 \mathrm{mg} / \mathrm{dL}$ and $398 \mathrm{mg} / \mathrm{dL}$; thus, this immunoglobulin was not decreased in any of them. All three tested negative for AGAA and EmA, and did not present diarrhea or anemia.

\section{IgA antiendomysium antibodies}

EmA was positive in $49.5 \%$ and negative in $50.5 \%$ of the samples at a 1:2.5 dilution.

Testing was done at a 1:5 dilution only on sera that had tested positive at $1: 2.5$; in this case, $21.7 \%$ of the samples were positive.

At 1:40, 11 sera tested positive $(5.8 \%)$; three were SLE patients, four were RA patients and four patients had ankylosing spondilitis. None of these 11 patients presented diarrhea or anemia (Table 2).

\section{$\operatorname{Ig} A$ and $\lg G$ antigliadin antibodies and $\lg A$ antiendomysium antibodies}

There was a significant difference between EmA positive results at 1:2.5 and 1:40 dilution relative to the AGAA; this difference, however, was not present relative to the AGAG (Table 3).

TABLE 1. Comparison of optic density readings of class IgA and IgG antigliadin antibodies in 190 rheumatologic patients

\begin{tabular}{|c|c|c|c|c|c|c|c|c|}
\hline Variable & Diagnosis & $\mathrm{n}$ & Mean & Standard deviation & Minimum & Maximum & Median & $P$ value* \\
\hline \multirow[t]{4}{*}{ AGAA } & SLE & 69 & 0.011 & 0.012 & 0.000 & 0.076 & 0.008 & 0.102 \\
\hline & Rheumatoid arthritis & 48 & 0.015 & 0.016 & 0.000 & 0.102 & 0.010 & \\
\hline & Juvenile rheumatoid arthritis & 32 & 0.009 & 0.012 & 0.000 & 0.051 & 0.005 & \\
\hline & Spondyloarthropathies & 41 & 0.011 & 0.008 & 0.000 & 0.032 & 0.010 & \\
\hline \multirow[t]{4}{*}{ AGAG } & SLE & 69 & 0.022 & 0.025 & 0.000 & 0.163 & 0.018 & 0.241 \\
\hline & Rheumatoid arthritis & 48 & 0.029 & 0.027 & 0.000 & 0.148 & 0.021 & \\
\hline & Juvenile rheumatoid arthritis & 32 & 0.022 & 0.019 & 0.000 & 0.076 & 0.021 & \\
\hline & Spondyloarthropathies & 41 & 0.023 & 0.023 & 0.000 & 0.197 & 0.017 & \\
\hline
\end{tabular}

AGAA: IgA class antigliadin antibodies; AGAG: IgG class antigliadin antibodies; SLE: Systemic lupus erythematosus

*Kruskal-Wallis test

TABLE 2. Comparison of antiendomysium antibody positivity at a 1:40 dilution in 190 rheumatologic patients

\begin{tabular}{|c|c|c|c|c|c|}
\hline & $\mathrm{n} / \%$ & Positive & Negative & Total & $P$ value* \\
\hline \multirow[t]{2}{*}{ SLE } & $\mathrm{n}$ & 3 & 66 & 69 & 0.262 \\
\hline & $\%$ & 4.3 & 95.7 & 100 & \\
\hline Rheumatoid arthritis & $\mathrm{n}$ & 4 & 44 & 48 & \\
\hline Juvenile rheumatoid arthritis & $\%$ & 8.3 & 91.7 & 100 & \\
\hline Spondyloarthropathies & $\mathrm{n}$ & 0 & 32 & 32 & \\
\hline Rheumatoid arthritis & $\%$ & 0.0 & 100.0 & 100 & \\
\hline \multirow[t]{2}{*}{ Juvenile rheumatoid arthritis } & $\mathrm{n}$ & 4 & 37 & 41 & \\
\hline & $\%$ & 9.8 & 90.2 & 100 & \\
\hline \multirow[t]{2}{*}{ Total } & $\mathrm{n}$ & 11 & 179 & 190 & \\
\hline & $\%$ & 5.8 & 94.2 & 100 & \\
\hline
\end{tabular}

SLE: Systemic lupus erychematosus

*chi-square test

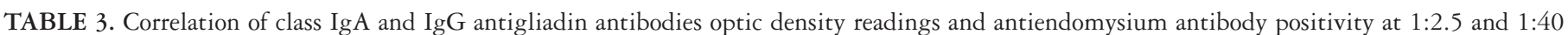
serum dilutions in 190 rheumatologic patients

\begin{tabular}{|c|c|c|c|c|c|c|}
\hline \multirow[b]{2}{*}{ AGAA } & \multicolumn{2}{|c|}{ End2,5 } & \multirow[b]{2}{*}{$P$ value* } & \multicolumn{2}{|c|}{ End40 } & \multirow[b]{2}{*}{$P$ value* } \\
\hline & $\begin{array}{l}\text { positive } \\
(\mathrm{n}=94)\end{array}$ & $\begin{array}{l}\text { negative } \\
(\mathrm{n}=96)\end{array}$ & & $\begin{array}{l}\text { positive } \\
(\mathrm{n}=11)\end{array}$ & $\begin{array}{c}\text { negative } \\
(\mathrm{n}=179)\end{array}$ & \\
\hline Mean & 0.013 & 0.011 & 0.019 & 0.024 & 0.024 & 0.003 \\
\hline Median & 0.011 & 0.007 & & 0.019 & 0.018 & \\
\hline Standard deviation & 0.010 & 0.015 & & 0.025 & 0.028 & \\
\hline Minimum & 0.000 & 0.000 & & 0.000 & 0.000 & \\
\hline Maximum & 0.042 & 0.102 & & 0.163 & 0.197 & \\
\hline AGAG & $\begin{array}{l}\text { positive } \\
(\mathrm{n}=94)\end{array}$ & $\begin{array}{l}\text { negative } \\
(\mathrm{n}=96)\end{array}$ & $P$ value* & $\begin{array}{l}\text { positive } \\
(\mathrm{n}=11)\end{array}$ & $\begin{array}{c}\text { negative } \\
(\mathrm{n}=179)\end{array}$ & $P$ value* \\
\hline Mean & 0.019 & 0.011 & 0.904 & 0.017 & 0.025 & 0.609 \\
\hline Median & 0.021 & 0.008 & & 0.018 & 0.019 & \\
\hline Standard deviation & 0.009 & 0.013 & & 0.010 & 0.027 & \\
\hline Minimum & 0.004 & 0.000 & & 0.002 & 0.000 & \\
\hline Maximum & 0.030 & 0.102 & & 0.037 & 0.197 & \\
\hline
\end{tabular}

AGAA: IgA class antigliadin antibodies

AGAG: IgG antigliadin antibodies;

End2,5: IgA antiendomysium antibodies at a 1:2.5 dilution;

End40: IgA antiendomysium antibodies at a 1:40 dilution.

*Mann-Whitney test 
Spearman's correlation was 0.17 when correlating AGAA optic density readings with EmA positive results at a 1:2.5 dilution.

Spearman's correlation was 0.22 when correlating AGAA optic density readings and EmA positive results at a 1:40 dilution.

Thus, higher AGAA optic density readings increase the possibility of higher EmA positive results as shown by Spearman's correlation above.

\section{Tissue IgA antitransglutaminase antibodies}

All $11 \mathrm{EmA}$ positive sera at a 1:40 dilution were also tested for tTG, and all were negative for these antibodies. The tTG was not tested in other patients.

\section{IgA and IgG antigliadin antibodies and medication}

The 190-patients sample was divided into two medication groups: patients in the first group took only non-steroidal anti-inflammatory drugs and/or chloroquine diphosphate (n
$=45)$; patients in the second group took prednisone and/or immunosuppressants $(\mathrm{n}=145)($ Table 4$)$.

Patients were further divided into two groups to assess the dose effect of prednisone on antibodies: one group consisted of patients taking non-steroidal anti-inflammatory drugs and/or analgesics and/or chloroquine diphosphate and/or prednisone $\leq 5 \mathrm{mg} /$ day $(\mathrm{n}=65)$; the other group consisted of patients taking prednisone $>5 \mathrm{mg} /$ day and/or immunosuppressants $(\mathrm{n}=125)$ (Table 5).

There was no association between AGAA and AGAG optic density readings and these groups taking different drugs.

\section{Antiendomysium antibodies and medication}

EmA positivity at a 1:2.5 dilution was compared with medication use in the same groups of patients; no association was found at this dilution (Table 6).

TABLE 4. Correlation of class IgA and IgG antigliadin antibodies optic density readings and medication use in 190 rheumatologic patients

\begin{tabular}{|c|c|c|c|c|c|c|}
\hline & \multicolumn{2}{|l|}{ AGAA } & \multirow[b]{2}{*}{$P$ value $*$} & \multicolumn{2}{|c|}{ AGAG } & \multirow[b]{2}{*}{$P$ value } \\
\hline & $\begin{array}{l}\begin{array}{l}\text { Using NSAIDs and/or CDF } \\
(\mathrm{n}=45)\end{array} \\
\end{array}$ & $\begin{array}{l}\text { Other medication } \\
\quad(\mathrm{n}=145)\end{array}$ & & $\begin{array}{l}\text { Using NSAIDs and/or CDF } \\
(\mathrm{n}=45)\end{array}$ & $\begin{array}{l}\text { Other medication } \\
\quad(\mathrm{n}=145)\end{array}$ & \\
\hline Mean & 0.012 & 0.012 & 0.677 & 0.018 & 0.026 & 0.120 \\
\hline Median & 0.011 & 0.008 & & 0.016 & 0.019 & \\
\hline Standard deviation & 0.012 & 0.013 & & 0.016 & 0.029 & \\
\hline Minimum & 0.000 & 0.000 & & 0.000 & 0.000 & \\
\hline Maximum & 0.076 & 0.102 & & 0.077 & 0.197 & \\
\hline
\end{tabular}

AGAA: class IgA antigliadin antibodies; AGAG: class IgG antigliadin antibodies; NSAIDs: non-steroidal antiinflammatory drugs; CDF: chloroquine diphosphate

*Mann-Whitney test

TABLE 5. Correlation of class IgA and IgG antigliadin antibody optic density readings with medication use relative to the daily dose of prednisone in 190 rheumatologic patients

\begin{tabular}{|c|c|c|c|c|c|c|}
\hline & \multicolumn{2}{|r|}{ AGAA } & \multirow[b]{2}{*}{$P$ value* } & \multicolumn{2}{|r|}{ AGAG } & \multirow[b]{2}{*}{$P$ value } \\
\hline & $\begin{array}{l}\text { Using NSAIDs } \\
\text { and/or CDF and/or } \\
\text { PDN } \leq 5 \mathrm{mg} \\
(\mathrm{n}=65)\end{array}$ & $\begin{array}{l}\text { Using immunosuppressant } \\
\text { and/or PDN }>5 \mathrm{mg} \\
(\mathrm{n}=125)\end{array}$ & & $\begin{array}{l}\text { Using NSAIDs } \\
\text { and/or CDF and/or } \\
\text { PDN } \leq 5 \mathrm{mg} \\
(\mathrm{n}=65)\end{array}$ & $\begin{array}{l}\text { Using immunosuppressant } \\
\text { and/or PDN }>5 \mathrm{mg} \\
(\mathrm{n}=125)\end{array}$ & \\
\hline Mean & 0.011 & 0.012 & 0.714 & 0.019 & 0.027 & 0.133 \\
\hline Median & 0.011 & 0.008 & & 0.017 & 0.019 & \\
\hline Standard deviation & 0.011 & 0.013 & & 0.015 & 0.031 & \\
\hline Minimum & 0.000 & 0.000 & & 0.000 & 0.000 & \\
\hline Maximum & 0.076 & 0.102 & & 0.077 & 0.197 & \\
\hline
\end{tabular}

AGAA: class IgA antigliadin antibodies; AGAG: class IgG antigliadin antibodies; NSAIDs: non-steroidal antiinflammatory drugs; CDF: chloroquine diphosphate; PDN: prednisone

*Mann-Whitney test

TABLE 6. Correlation of $\operatorname{IgA}$ antiendomysium antibody positivity at a 1:2.5 dilution with medication use in 190 rheumatologic patients

\begin{tabular}{|c|c|c|c|c|c|}
\hline End2,5 & & Using NSAIDs and/or CDF & Other medication & Total & $P$ value* \\
\hline \multirow[t]{2}{*}{ Positive } & $\mathrm{n}$ & 21 & 73 & 94 & 0.666 \\
\hline & $\%$ & 22.3 & 77.7 & 100 & \\
\hline \multirow[t]{2}{*}{ Negative } & $\mathrm{n}$ & 24 & 72 & 96 & \\
\hline & $\%$ & 25.0 & 75.0 & 100 & \\
\hline \multirow[t]{2}{*}{ Total } & $\mathrm{n}$ & 45 & 145 & 190 & \\
\hline & $\%$ & 23.7 & 76.3 & 100 & \\
\hline End2,5 & & Using NSAIDs and/or CDF and/or PDN $\leq 5 \mathrm{mg}$ & Using immunosuppressant and/or PDN $>5 \mathrm{mg}$ & Total & $P$ value* \\
\hline \multirow{2}{*}{ Positive } & $\mathrm{n}$ & 26 & 68 & 94 & 0.06 \\
\hline & $\%$ & 27.7 & 72.3 & 100 & \\
\hline \multirow[t]{2}{*}{ Negative } & $\mathrm{n}$ & 39 & 57 & 96 & \\
\hline & $\%$ & 40.6 & 59.4 & 100 & \\
\hline \multirow[t]{2}{*}{ Total } & $\mathrm{n}$ & 65 & 125 & 190 & \\
\hline & $\%$ & 34.2 & 65.8 & 100 & \\
\hline
\end{tabular}


However, there was a significant association between EmA positivity and medication use at 1:40 dilution. The proportion of EmA-positive subjects taking only non-steroidal anti-inflammatory drugs and/or chloroquine diphosphate was higher compared to patients taking other drugs. Thus, use of immunosuppressants and/or prednisone correlated with negative EmA results. This association became more evident when patients were subdivided according to the daily dose of prednisone (Table 7).

TABLE 7. Correlation of $\operatorname{Ig} A$ antiendomysium antibody positivity at a 1:40 serum dilution with use of medication in 190 rheumatologic patients

\begin{tabular}{|c|c|c|c|c|c|}
\hline End 40 & & $\begin{array}{l}\text { Using NSAIDs } \\
\text { and/or CDF }\end{array}$ & $\begin{array}{c}\text { Other } \\
\text { medication }\end{array}$ & Total & $P$ value \\
\hline \multirow[t]{2}{*}{ Positive } & $\mathrm{n}$ & 6 & 5 & 11 & 0.026 \\
\hline & $\%$ & 54.5 & 45.5 & 100 & \\
\hline \multirow[t]{2}{*}{ Negative } & $\mathrm{n}$ & 39 & 140 & 179 & \\
\hline & $\%$ & 21.8 & 78.2 & 100 & \\
\hline \multirow[t]{2}{*}{ Total } & $\mathrm{n}$ & 45 & 145 & 190 & \\
\hline & $\%$ & 23.7 & 76.3 & 100 & \\
\hline End 40 & & $\begin{array}{c}\text { Using NSAIDs } \\
\text { and/or CDF and/or } \\
\text { PDN } \leq 5 \mathrm{mg}\end{array}$ & $\begin{array}{c}\text { Using } \\
\text { immunosuppressant } \\
\text { and/or PDN }>5 \mathrm{mg}\end{array}$ & Total & $P$ value* \\
\hline \multirow[t]{2}{*}{ Positive } & $\mathrm{n}$ & 8 & 3 & 11 & 0.009 \\
\hline & $\%$ & 72.7 & 27.3 & 100 & \\
\hline \multirow[t]{2}{*}{ Negative } & $\mathrm{n}$ & 57 & 122 & 179 & \\
\hline & $\%$ & 31.8 & 68.2 & 100 & \\
\hline \multirow[t]{2}{*}{ Total } & $\mathrm{n}$ & 65 & 125 & 190 & \\
\hline & $\%$ & 34.2 & 65.8 & 100 & \\
\hline
\end{tabular}

\section{Antiendomysium and antigliadin antibody positivity and histological studies of the duodenum}

Upper digestive endoscopies with duodenal biopsies were carried out in 9 of 11 patients with positive antiendomysium antibodies and in all 7 patients with positive antigliadin antibodies (IgA or IgG). Testing was not done in 1 patient that died; another patient refused endoscopy.

Endoscopy of the bulbus and second portion of the duodenum were within normal limits macroscopically. No significant histological changes were found in the samples of duodenum (all were classified as March 0); thus, all patients were considered as having no histological signs of CD.

Assuming that no patient presented CD, the specificity of AGAA and AGAG were calculated at $97.9 \%$ and $98.4 \%$. Similarly, the specificity of EmA testing in our sample was $94.2 \%$.

\section{DISCUSSION}

Reports in the literature on the prevalence of $\mathrm{CD}$ in adult and child rheumatologic diseases are generally not uniform ${ }^{(3 .}$ $5,7,9,22)$. Most papers that mention any association between these conditions are based on small samples or case reports.

Fasano and Catassi ${ }^{(9)}$ estimated that the prevalence of CD among RA patients ranged from $1.5 \%$ to $7.5 \%$. Francis et al. ${ }^{(12)}$ studied 160 British patients with RA and found a single case of $\mathrm{CD}$ among them; a $0.63 \%$ prevalence, equal to that of the country as a whole. Similarly, Nisihara et al. ${ }^{(43)}$ in Brazil studied 85 RA patients and 97 healthy controls, and found no EmA positive results in any of them.
Paimela et al. ${ }^{(44)}$ studied 78 RA patients and found that AGA (IgA and/or IgG) was positive in $37 \%$ of these subjects and in $12 \%$ of controls. Histological studies of the intestine did not reveal enteropathies in any subject.

Feighery et al. ${ }^{(11)}$ undertook EmA testing in $53 \mathrm{RA}$ patients and 46 SLE patients. No SLE patient tested positive; there was a single positive case in the RA group, but no intestinal biopsy was done. On the other hand, guinea-pig enzyme tTG testing yielded an $11 \%$ positive rate in RA subjects and a $22 \%$ positive rate in SLE subjects; CD was not confirmed in any of these patients.

Rensch et al. ${ }^{(47)}$ found a $23 \%$ positivity rate for at least one class of antigliadin antibodies in 103 SLE patients; none of these patients had intestinal signs of CD. EmA testing was negative in all cases.

Marai et al. ${ }^{(34)}$ tested 100 SLE patients for tTG using human recombinant enzymes and found a single case of CD.

Kallikorm et al. ${ }^{(24)}$ studied 74 hospitalized patients with various spondyloarthropathies and found one case of $\mathrm{CD}$. AGAA were positive in $12 \%$ of these cases, AGAG were positive in $4 \%$, and EmA tested positive only in the single confirmed enteropathy case.

Lindqvist et al. ${ }^{(31)}$ found $5 \mathrm{CD}$ cases in 144 psoriatic arthritis patient (4.4\% prevalence rate) in this sample. None of these patients were EmA-positive, which was attributed to mild intestinal vilosity atrophy in their histological analysis. All cases were AGAA-positive; antibody titers in these patients with arthritis were significantly higher compared to controls after excluding patients with $\mathrm{CD}$.

JRA is one of the most common rheumatic diseases in children, although there is no consensus on whether the prevalence of $\mathrm{CD}$ is higher or not in such patients ${ }^{(38)}$. George et al. ${ }^{(14)}$ estimated a $0.4 \%$ to $2 \%$ prevalence of CD in JRA patients. Stagi et al. ${ }^{(52)}$ found $10 \mathrm{CD}$ cases $(6.6 \%)$ in $151 \mathrm{JRA}$ pediatric patients, a much higher percentage than that of the local population. Similarly, Lepore et al. ${ }^{(30)}$ found 4 EmA-positive cases in 119 JRA children; 3 of these children had asymptomatic intestinal vilosity atrophy, a $2.5 \%$ prevalence rate of $\mathrm{CD}$ in this sample.

Serum dilutions in antiendomysium antibody testing for defining positive results vary widely among authors. Kotze et al. ${ }^{(25)}$ used a 1:2.5 dilution; Johnston et al. ${ }^{(23)}$ used a 1:5 dilution; Leon et al. ${ }^{(29)}$ used a 1:10 dilution; and Ghedira et al. ${ }^{(15)}$ used a 1:50 dilution.

Bahia et al.(1) found 39 positive EmA tests at a 1:2.5 dilution in 173 controls with no gastrointestinal complaints; none of them had CD. At a 1:40 dilution none of these patients tested positive for EmA. Based on their statistical analysis, these authors concluded that $1: 40$ would be the ideal dilution to identify $C D$ patients.

We found that the serum dilution clearly influenced the positive EmA results (fluorescence pattern indicating a positive result), as follows: at a 1:2.5 dilution the positive rate was $49.5 \%$; at a $1: 5$ dilution, the positive rate was $21.7 \%$; and at a 1:40 dilution, the positive rate was only $5,8 \%$.

There may be more than one explanation for the absence of histological findings suggesting $\mathrm{CD}$ and the tTG-negative results in the 11 EmA-positive patients in our sample: one could be the presence in these patients of other IgA class autoantibodies not directed against tissue transglutaminases, which would bind to 
human umbilical cord antigens and fluoresce in a similar pattern to that of $\mathrm{CD}$. It should be noted that this group consisted of patients with rheumatologic autoimmune diseases in which a variety of autoantibodies - such as anti-smooth muscle antibodies - were produced, which generally make it harder to test EmA at lower dilutions ${ }^{(28,33,55)}$. Anti-smooth muscle antibodies and other autoantibodies were not tested in this study. Negative tTG results in EmA-positive patients suggest that this second test is more specific in rheumatologic patients with autoimmune disease. All subjects would have had to be tested to demonstrate this possibility.

A less likely explanation for positive EmA tests in our sample could be a less than adequate interpretation of slides, given the subjective nature of the evaluation of fluorescence, or even procedural failure when carrying out the tests. The same examiner that interpreted the slides found no positive results in a previous study of 312 patients without $C D$, using the same material and methods at a 1:40 dilution in the same laboratory ${ }^{(1)}$.

Positive EmA tests in subjects with no histological findings for $\mathrm{CD}$ may indicate a latent form of this condition that may manifest in future. Serological and histological follow-up of these patients across the years could confirm this possibility.

EmA positivity was related with AGAA-testing optic density readings, but not with IgG testing. In other words, EmA-positive sera had higher AGAA readings compared to negative sera for these antibodies. This appears to reflect an increased production of a variety of IgA class antibodies in EmA-positive subjects.

Although controversial, many authors have suggested that prednisone and other immunosuppressants, especially at high doses, may decrease antibody production ${ }^{(2,10,20,45)}$. However, there was no significant difference in AGAA and AGAG test optic density readings in our patients using these drugs or not.
On the other hand, prednisone and other immunosuppressant drug use were inversely related with EmA positivity: patients taking these drugs had a lower rate of positive EmA tests, which suggested that fewer of the antibodies detected by fluorescence in this group were being produced.

Histology of duodenal biopsies in our sample did not show significant changes. This was probably due to the absence of CD or other enteropathies. We cannot, however, discard completely the influence of prednisone and other immunosuppressants on our results, since these drugs may decrease structural and inflammatory alterations of the small intestine $e^{(16,36,39,50)}$.

\section{CONCLUSION}

In conclusion, our study suggests that positive AGAA, AGAG or EmA results generally do not imply in the presence of $\mathrm{CD}$ in patients with autoimmune rheumatologic disease with no classical clinical manifestations of this enteropathy. Further studies are needed to assess the prevalence of $C D$ in rheumatologic patients with greater accuracy.

\section{ACKNOWLEDGEMENTS}

Prof. Marco Antônio Parreiras de Carvalho (Division of Rheumatology, Medical School of the Federal University of Minas Gerais, Belo Horizonte, MG), Prof. Lorete Maria da Silva Kotze (Medical School of the Federal University of Paraná, Curitiba, PR), and the medical students Marcelo Fonseca Marinho, Paulo Carvalho Pimenta Figueiredo and Renato Olegário Leite Pereira (Medical School of the Federal University of Minas Gerais).

Koehne VB, Bahia M, Lanna CCD, Pinto MRC, Bambirra EA, Cunha AS. Pesquisa de anticorpos antigliadina (classes IgA e IgG) e anticorpos antiendomísio classe IgA, em pacientes com doenças reumatológicas autoimunes em Belo Horizonte, MG, Brasil. Arq Gastroenterol. 2010;47(3):250-6.

RESUMO - Contexto - Tanto os pacientes com doenças reumatológicas autoimunes quanto os com doença celíaca costumam apresentar vários tipos de autoanticorpos, muitos deles ainda sem papel definido na etiopatogênese dessas afecções. Apesar de tratar-se de assunto controverso, é bastante citada na literatura a maior prevalência da doença celíaca em diversos grupos de pacientes reumatológicos. Objetivo - Investigar a prevalência de marcadores sorológicos positivos para doença celíaca: anticorpos antigliadina (AGA) classes IgA e IgG (AGAA e AGAG) e anticorpos antiendomísio classe IgA (EmA), em pacientes com doenças reumatológicas autoimunes. Procurou-se também avaliar a correlação entre a positividade dos testes sorológicos com o uso de prednisona e de medicamentos imunossupressores. Métodos - Foram avaliados 190 pacientes adultos e pediátricos com doenças reumatólogicas variadas (lúpus eritematoso sistêmico, artrite reumatóide, artrite reumatóide juvenil e espondiloartropatias. Em todos foram realizadas pesquisas de AGAA e AGAG e de EmA, encaminhando-se os casos positivos para biopsias endoscópica duodenal e estudos histológicos. Resultados - Houve quatro soros positivos (2,1\%) para AGAA, todos com resultados negativos para AGAG e EmA. Três soros $(1,6 \%)$ tiveram resultados positivos para AGAG, todos com resultados negativos para AGAA e EmA. Na pesquisa de EmA, a diluição do soro em 1:2,5 mostrou resultados positivos em 94 pacientes (49,5\%) e na diluição de 1:5, em 41 (21,6\%). Em 11 indivíduos obteve-se resultado positivo para EmA na diluição 1:40 e todos eles tiveram resultado negativo para a pesquisa de anticorpos antitransglutaminase tecidual IgA (tTg). Nove dos 11 pacientes positivos para EmA e todos os 7 pacientes com anticorpos antigliadina positivos foram submetidos a biopsia duodenal endoscópica, não se constatando alterações significativas da mucosa duodenal em nenhum deles. Todos os soros positivos para EmA apresentaram resultados negativos para a pesquisa de anticorpos antitransglutaminase tecidual classe IgA (tTG). A positividade para EmA associou-se a leituras de densidade óptica mais altas para AGAA. O mesmo não foi observado para AGAG. O uso de prednisona e de imunossupressores não se relacionou às leituras de densidade óptica dos AGAA, tampouco dos AGAG. O uso dessas medicações se relacionou, contudo, a menor positividade para EmA. Conclusão - Resultados positivos para AGAA, AGAG ou EmA demonstraram-se inespecíficos para a presença de doença celíaca em pacientes com doenças reumatológicas autoimune. $\mathrm{O}$ uso de prednisona e drogas imunossupressoras parece diminuir a prevalência de anticorpos antiendomísio IgA, mas não de anticorpos antigliadina. Mais estudos são necessários para se avaliar com maior precisão a prevalência da doença celíaca em pacientes reumatológicos.

DESCRITORES - Doença celíaca. Doenças reumáticas. Testes sorológicos. 


\section{REFERENCES}

1. Bahia M, Penna FJ, Sampaio IB, Silva GM, Andrade EM. Determining IgA and $\mathrm{IgG}$ antigliadin, IgA antitransglutaminase, and antiendomysial antibodies in monkey esophagus and in umbilical cord for diagnosis of celiac disease in developing countries. J Pediatr Gastroenterol Nutr. 2007;45:551-8.

2. Calabresi P, Parks Jr RE. Agentes antiproliferativos e substâncias imunossupressoras. In: Gilman AG, Goodman LS, Gilman A, editors. As bases farmacológicas da terapêutica. $6^{a}$ ed. Rio de Janeiro: Guanabara Koogan; 1983. p.1100-48.

3. Catassi C, Kryszak D, Louis-Jacques O, Duerksen DR, Hill I, Crowe SE, Brown AR, Procaccini NJ, Wonderley BA, Hartley P, Moreci J, Bennett N, Horvath K, Burk M, Fasano A. Detection of celiac disease in primary care: a multicenter case-finding study in North America. Am J Gastroenterol. 2007;102:1454-60.

4. Chorzelski TP, Sulej J, Tchorzewska H, Jablonska S, Beutner EH, Kumar V. IgA class endomysium antibodies in dermatitis herpetiformis and celiac disease. Ann N Y Acad Sci. 1983;420:325-34

5. Delbrel X, Le-Bougeant P, Etienne G, Blanco P, Beylot-Barry M, Amouretti M, Mercie P, Longy-Boursier M. Celiac disease and autoimmune diseases or systemic disease. Six cases and a review of the literature. Ann Med Intern. 2003;154:197-204.

6. Dubé C, Rostom A, Sy R, Cranney A, Saloojee N, Garritty C, Sampson M Zhang L, Yazdi F, Mamaladze V, Pan I, Macneil J, Mack D, Patel D, Moher D. The prevalence of celiac disease in average-risk and at-risk western european populations: a systematic review. Gastroenterology. 2005;128:s57-67.

7. Farrel RJ, Kelly CP. Celiac sprue. N Engl J Med. 2002;346:180-8.

8. Fasano A, Catassi C. Current approaches to diagnosis and treatment of celiac disease: an evolving spectrum. Gastroenterology. 2001;120:636-51.

9. Fasano A, Berti I, Gerarduzzi T, Not T, Colletti RB, Drago S, Elitsur Y, Green PH, Guandalini S, Hill ID, Pietzak M, Ventura A, Thorpe M, Kryszak D, Fornaroli, Wasserman SS, Murray JA, Horvath K. Prevalence of coeliac disease in at-risk and not-at-risk groups in the United States: a large multicenter study. Arch Intern Med. 2003;163:286-92.

10. Fedor ME, Rubinstein A. Effects of long-term low dose corticosteroid therapy on humoral immunity. Ann Allergy Asthma Immunol. 2006:97:113-6.

11. Feighery L, Collins C, Feighery C, Mahmud N, Coughlan G, Willoughby R, Jackson J. Anti-transglutaminase antibodies and the serological diagnosis of coeliac disease. Br J Biomed Sci. 2003;60:14-8.

12. Francis J, Carty JE, Scott BB. The prevalence of celiac disease in rheumatoid arthritis. Eur J Gastroenterol Hepatol. 2002;14:1355-6.

13. Gandolfi L, Pratesi R, Cordoba JC, Tauil PL, Gasparin M, Catassi C. Prevalence of celiac disease among blood donors in Brazil. Am J Gastroenterol. 2000;95:689-92.

14. George EK, Hertzberger-tem Cate R, van Suijlekom-Smit LW, von Blomberg BM, Stapel SO, van Elburg RM, Mearin ML. Juvenile chronic arthritis and coeliac disease in The Netherlands. Clin Exp Rheumatol. 1996;14:571-5.

15. Ghedira I, Sghiri R, Ayadi A, Sfar MT, Harbi A, Essoussi AS, Amri F, Korbi S, Jeddi M. [Anti-endomysium, anti-reticulin and anti-gliadin antibodies, value in the diagnosis of celiac disease in the child] Pathol Biol (Paris). 2001;49:47-52.

16. Goerres MS, Meijer JW, Wahab PJ, Kerckhaert JA, Groenen PJ, Van Krieken $\mathrm{JH}$, Mulder CJ. Azathioprine and prednisone combination therapy in refractory coeliac disease. Aliment Pharmacol Ther. 2003;18:487-94.

17. Green PH, Barry M, Matsutani M. Serologic tests for celiac disease. Gastroenterology 2003;124:585-6.

18. Green PH. The many faces of celiac disease: clinical presentation of celiac disease in the adult population. Gastroenterology. 2005;128:s74-8

19. Hadivassiliou M, Sanders DS, Grünewald RA, Akil M. Gluten sensitivity masquerading as systemic lupus erythematosus. Ann Rheum Dis. 2004;63:1501-3.

20. Hanania NA, Sockrider M, Castro M, Holbrook JT, Tonascia J, Wise R, Atmar RL, American Lung Association Asthma Clinical Research Centers. Immune response to influenza vaccination in children and adults with asthma: effect of corticosteroid therapy. J Allergy Clin Immunol. 2004;113:717-24.

21. Hill ID, Dirks MH, Liptak GS, Colletti RB, Fasano A, Guandalini S, Hoffenberg EJ, Horvath K, Murray JA, Pivor M, Seidman EG. Guideline for the diagnosis and treatment of celiac disease in children: recommendations of the North American Society for Pediatric Gastroenterology, Hepatology and Nutrition. J Pediatr Gastroenterol Nutr. 2005;40:1-19.

22. Jackson Allen PL. Guidelines for the diagnosis and treatment of celiac disease. Pediatr Nurs. 2004;30:473-6.

23. Johnston SD, McMillan SA, Collins JS, Tham TC, McDougall NI, Murphy P. A comparison of antibodies to tissue transglutaminase with conventional serological tests in the diagnosis of celiac disease. Eur J Gastroenterol Hepatol. 2003;15:1001-4.

24. Kallikorm R, Uibo O, Uibo R. Coeliac disease in spondyloarthropathy: usefulness of serological screening. Clin Rheumatol. 2000;19:118-22.

25. Kotze LM, Utiyama SR, Nisihara RM, Zeni MP, de Sena MG, Amarante HM. Antiendomysium antibodies in brazilian patients with celiac disease and their first-degree relatives. Arq Gastroenterol. 2001;38:94-103

26. Kotze LMS. Doença celíaca. In: Condutas em Gastroenterologia. Federação Brasileira de Gastroenterologia. Rio de Janeiro: Revinter; 2004. p.177-97.

27. Kumar V, Rajadhyasha M, Wortsman J. Celiac disease-associated auto-immune endocrinopathies. Clin Diagn Lab Immunol. 2001;8:678-85.
28. Lasagni D, Ferrari R, Lapini M. Unmasking anti-endomysial antibodies in coeliac subjects positive for anti-smooth muscle antibodies. Acta Pædiatr. 1999;88:462-4

29. Leon F, Camarero C, R-Pena R, Eiras P, Sanchez L, Baragaño M, Lombardia M, Bootello A, Roy G. Anti-transglutaminase IgA Elisa: clinical potential and drawbacks in celiac disease diagnosis. Scand J Gastroenterol. 2001;36:849-53.

30. Lepore L, Martelossi S, Pennesi M, Falcini F, Ermini ML, Ferrari R, Perticarari S, Presani G, Lucchesi A, Lapini M, Ventura A. Prevalence of celiac disease in patients with juvenile chronic arthritis. J Pediatr. 1996;129:311-3.

31. Lindqvist U, Rudsander A, Boström A, Nilsson B, Michaäelsson G. IgA antibodies to gliadin and coeliac disease in psoriatic arthritis. Rheumatology. 2002;41:31-7.

32. Lock RJ, Unsworth DJ. Identifying immunoglobulin-A-deficient children and adults does not necessarily help the serologic diagnosis of coeliac disease. J Pediatr Gastroenterol Nutr. 1999;28:81-3.

33. Luft LM, Barr SG, Martin LO, Chan EK, Fritzler MJ. Autoantibodies to tissue transglutaminase in Sjögren's syndrome and related rheumatic diseases. J Rheumatol 2003;30:2613-9.

34. Marai I, Shoenfeld Y, Bizzaro N, Villalta D, Doria A, Tonutti E, Tozzoli R. IgA and IgG tissue transglutaminase antibodies in systemic lupus erythematosus. Lupus. 2004;13:241-4.

35. Marsh MN. Mucosal pathology in gluten sensitivity. In: Marsh, MN, editor Coeliac disease. Oxford: Blackwell Scientific Publications; 1992. p.136-91.

36. Mauriño E, Niveloni S, Cherñavsky A, Pedreira S, Mazure R, Vazquez H, Reyes H, Fiorini A, Smecuol E, Cabanne A, Capucchio M, Kogan Z, Bai JC. Azathioprine in refractory sprue: results from a prospective, open-label study. Am J Gastroenterol. 2002;97:2595-602.

37. Melo SB, Fernandes MI, Peres LC, Troncon LE, Galvão LC. Prevalence and demographic characteristics of celiac disease among blood donors in Ribeirão Preto, state of São Paulo, Brazil. Dig Dis Sci. 2006;51:1020-5.

38. Miller ML. Clinical aspects of juvenile rheumatoid arthritis. Curr Opin Rheumatol. 1997;9:423-7.

39. Mitchison HC, al Mardini H, Gillespie S, Laker M, Zaitoun A, Record CO. A pilot study of fluticasone propionate in untreated coeliac disease. Gut. 1991;32:260-5.

40. Mondher Z, Daoud W, Kallel M, Makni S. Systemic lupus erythematosus with celiac disease: a report of five cases. Joint Bone Spine. 2004;71:344-6.

41. Mukamel M, Rosenbach Y, Zahavi I, Mimouni M, Dinari G. Celiac disease associated with systemic erythematosus lupus. Isr J Med Sci. 1994;30:656-8.

42. Nisihara RM, Kotze LM, Utiyama SR. Prevalência de doença celíaca na região no sul do Brasil. In: V Semana Brasileira do aparelho Digestivo. Anais do V Semana Brasileira do aparelho Digestivo. Rio de Janeiro;2002. p.19-20.

43. Nisihara RM, Skare TL, Silva MB, Utyiama SR. Rheumatoid arthritis and antiendomysial antibodies. Acta Reumatol Port. 2007;32:163-7.

44. Paimela L, Kurki P, Leirisalo-Repo M, Piirainen H. Gliadin immune reactivity in patients with rheumatoid arthritis. Clin Exp Rheumatol. 1995;13:603-7.

46. Pratesi R, Gandolfi L, Garcia SG, Modelli IC, Lopes de Almeida P, Bocca AL, Catassi C. Prevalence of coeliac disease: unexplained age-related variation in the same population. Scand J Gastroenterol. 2003;38:747-50.

47. Rensch MJ, Szyjkowski R, Shaffer RT, Fink S, Kopecky C, Grissmer L, Enzenhauer $\mathrm{R}$, Kadakia S. The prevalence of celiac disease autoantibodies in patients with systemic lupus erythematosus. Am J Gastroenterol. 2001;96:1113-5.

48. Rewers M. Epidemiology of celiac disease: what are the prevalence, incidence, and progression of celiac disease? Gastroenterology. 2005;128:s47-51.

49. Rodrigo L. Celiac disease. World J Gastroenterol. 2006;12:6585-93

50. Rostom A, Murray JA, Kagnoff MF. American Gastroenterological Association (AGA). Institute Technical Review on the Diagnosis and Management of Celiac Disease. Gastroenterology. 2006;131:1981-2002.

51. Rostom A, Dubé C, Cranney A, Saloojee N, Sy R, Garritty C, Sampson M, Zhang L, Yazdi F, Mamaladze V, Pan I, MacNeil J, Mack D, Patel D, Moher D. The diagnostic accuracy of serologic tests for celiac disease: a systematic review. Gastroenterology. 2005; 128:s38-46.

52. Stagi S, Giani T, Simonini G, Falcini F. Thyroid function, autoimmune thyroiditis and coeliac disease in juvenile idiopathic arthritis. Rheumatology. 2005;44:517-20.

53. Talal AH, Murray JA, Goeken JA, Sivitz WI. Celiac disease in an adult population with insulin-dependent diabetes mellitus: use of endomysial antibody testing. Am J Gastroenterol. 1997:92:1280-4.

54. Volta U, Lenzi M, Lazzari R, Cassani F, Collina A, Bianchi FB, Pisi E. Antibodies to gliadin detected by immunofluorescence and a micro-ELISA method: markers of active childhood and adult coeliac disease. Gut. 1985;26:667-71.

55. Volta U, Molinaro N, de Franceschi L, Fratangelo D, Bianchi FB. IgA antiendomysial antibodies on human umbilical cord tissue for celiac disease screening save both money and monkeys. Dig Dis Sci. 1995;40:1902-5.

56. Volta U, Rodrigo L, Granito A, Petrolini N, Muratori P, Muratori L, Linares A, Veronesi L, Fuentes D, Zauli D, Bianchi FB. Celiac disease in autoimmune cholestatic liver disorders. Am J Gastroenterol. 2002;97:2609-13.

Received 23/9/2009 Accepted 26/1/2010. 